\title{
ANALYSIS OF INTEREST IN VACCINATION AGAINST COVID-19 AND OTHER PRO-HEALTH INITIATIVES AT THE WORKPLACE AMONG EMPLOYEES IN POLAND
}

\author{
Agata Olearczyk, Dominik Olejniczak \\ Medical University of Warsaw, Warsaw, Poland \\ Public Health Department
}

\begin{abstract}
Background: The COVID-19 pandemic re-raised the subject of vaccines and their importance for public health. Given the number of employees, one of the key environments in which vaccination should be promoted is the workplace. Material and Methods: An original, anonymous and voluntary questionnaire with 13 questions regarding health behaviors of employees in Poland was distributed through HR departments of the companies invited to the research (Computer-Assisted Web Interview - CAWI technique) This publication presents the results of answers to the 3 chosen questions concerning: health issues related to work, interest in health promoting initiatives and following recommendations for physical activity. Results: According to the research presented in this article, $39 \%$ of employees in Poland were interested in vaccination against COVID-19. The most popular preventive initiatives are still healthy eating and sport activities. The government allowed organizing vaccinations at the workplace, which gives new opportunities but also obligations and risks. Overall, the potential of a workplace in fighting the coronavirus seems to be used to a very small extent. This carries the need to consult systemic solutions with representatives of employers and occupational medicine practitioners as well as the government. Conclusions: The workplace should be one of the key habitats for health promoting activities, including vaccinations. The above-mentioned issue should still be the subject of research for solutions tailored to the needs and capabilities of each group (employers, occupational medicine professionals and government). One of the circumstances of promoting the health of employees should be preventive examinations of employees - a doctor's visit and contact with an occupational medicine nurse. The potential of preventive employee examinations in this area seems to be unused and limited. The level of immunization of employees has an obvious impact on the state of the economy. In view of the voluntary vaccination against COVID-19, this requires educational campaigns aimed at both employees and employers. Med Pr. 2021;72(6):653-9
\end{abstract}

Key words: workplace, employee, vaccination, public health, coronavirus, pandemic

Corresponding author: Agata Olearczyk, Medical University of Warsaw, Public Health Department, Nielubowicza 5, 02-097 Warsaw, Poland, e-mail: aolearczyk@wum.edu.pl

Received: July 11, 2021, accepted: December 2, 2021

\section{INTRODUCTION}

The pandemic of COVID-19 (as of October 13, 2021, approx. 219 million cases worldwide) [1] has changed the perception of global health threats, especially among people not related to healthcare system. The public health has come to the fore and the epidemiological situation has shown that it is impossible to cope with a disease on a global scale without cooperation and joint actions of a disciplined and well-educated society. Therefore, the importance of public health, especially in the case of infectious diseases, is very clearly articulated.

The essence of public health policy, particularly in the context of new health threats is firstly about predicting them, and secondly about preparing societies for functioning in conditions of health risk. The pandemic of COVID-19 has proven beyond any doubt that it is only through "an organized effort of the entire society" - an inherent component of public health, that the global health threat can be brought under control [2].

Based on forecasts and models it can be predicted that conditions such as epidemics or pandemics will occur regularly. That being so, it is crucial to respond accordingly and competently to such threats. At the same time, it should be kept in mind that the definition of health applies not only to the somatic, but also mental, social as well as economic areas, which is particularly important from the point of view of employees, employers, and the scale of the national macroeconomy. The obvious impact of the pandemic on this area necessitates a conduction of analysis related to the health of the working population.

Vaccinations are considered to be one of the greatest achievements of medicine. Thanks to them it was possible to eliminate many health problems, such as 
smallpox. Moreover, compulsory vaccinations contributed to the near eradication of diseases such as measles, whooping cough and polio.

Since the outbreak of the pandemic, intensive work has been carried out in order to develop vaccines against COVID-19. On November 9, 2020, the companies Pfizer-BioNTech announced a breakthrough in the development of COVID-19 vaccine - they confirmed its effectiveness at the level of 90\%. On December 8, 2020, the first vaccination with the Pfizer-BioNTech vaccine took place in the UK already - it is worth noting that it took place outside of clinical trials [3]. Shortly after, the first vaccine was administrated in Poland, on December 27 of the same year. The World Health Organization emphasizes that immunization is one of the main tools in the fight against the coronavirus.

Since the inception of vaccinations in general they have been accompanied by various theories often unsupported by scientific evidence. The same is true of vaccinations against COVID-19. Since the start of the pandemic there have been numerous activities that not only question the need for vaccinations, but also deny the pandemic itself and undermine all scientific evidence. In this context one of the main challenges for public health is the promotion of information based on reliable medical knowledge (evidence-based medicine) and - along this path - the fight against the socalled fake news. It is also a significant issue in terms of health promotion at workplace - a population of just over 17 million people in Poland. Likewise, according to WHO the workplace is a habitat in which health promotion can and should take place, including encouraging vaccination [4]. However, vaccination against COVID-19 didn't outweigh the most popular preventive initiatives among employees, such as healthy eating or financing sport activities. The aim of this work is to present level of employees' interest in vaccinations against COVID-19 and other preventive initiatives at the workplace (stationary and online).

\section{MATERIAL AND METHODS}

The research used the CAWI technique (Computer-Assisted Web Interview), which is an online survey. The survey was made available through the Qualtrics tool which is a safe solution in terms of GDPR (General Data Protection Regulation). An original, anonymous and voluntary questionnaire was prepared consisting of 12 main questions in total regarding the health behaviors of employees in Poland. Seven of the questions were closed-ended and 5 of them had multiple-choice option. The invitation to the study was addressed to $>50$ companies, however the exact number may differ due to varies channels of distribution (the invitation has been sent by a team of people). At the first stage 21 of the companies that received the invitation declared their willing to participate in the research. Finally, 10 companies decided to participate and distributed the survey among employees through the HR departments. The study took place from September to October 2020. This publication presents the results of answers to the 3 chosen questions concerning the employees' interest in health promoting activities carried out by the employer. The first question was answered by 1957 employees, the second one by 1942 and the third one by 2035 employees. The vast majority of respondents in all 3 questions were office workers - 75\% $(\mathrm{N} 1=1468, \mathrm{~N} 2=1454, \mathrm{~N} 3=1517)$ from different industries: shared service, hi-tech, pharmaceutical and FMCG (Fast Moving Consumer Goods). The working conditions were mostly home office and the main occupational risk was working with a computer for $>4 \mathrm{~h}$. The rest were blue-collar workers $-25 \%(\mathrm{~N} 1=489$, $\mathrm{N} 2=488, \mathrm{~N} 3=518$ ) from the manufacturing industry. The working conditions were mostly at the workplace, with higher number of occupational risks - depending on the position. The average age in the total group was 35 years old (the youngest person was 20 years old and the oldest -67 years old).

\section{RESULTS}

\section{Most popular health issues related to work}

The first question "Do you suffer from any health issues related to your work specifics?" consisted of 9 answers with multiple-choice option. In this question women formed $42 \%$ of the respondents $(\mathrm{N} 1=829)$ and men $58 \%(\mathrm{~N} 1=1128)$. The vast majority of participants $(52 \%, \mathrm{~N}=1017)$ declared that they suffer from back pain due to their work specifics. It was followed by neck and shoulder pain $(39 \%, \mathrm{~N}=763)$. As third placed sight problems $(34 \%, \mathrm{~N}=656)$ followed by mental weakness $(33 \%, \mathrm{~N}=645)$. The answer about mental weakness includes nervousness, petulance, anxiety and depression). This trend is the same both for white-collars as well as the blue-collars.

Further health issues related to work are: headache $(26 \%, N=508)$, wrist ache $(16 \%, N=313)$, stomach pain $(9 \%, \mathrm{~N}=176)$ and other $(3 \%, \mathrm{~N}=58)$. There are also 352 employees that declare no work-related health 
issues (18\%). The distribution of the most popular health issues related to work is presented in Figure 1.

In the group of respondents from this article's research, $32 \%$ of them are overweight $(\mathrm{N}=700)$ and $12 \%$ $(\mathrm{N}=262)$ has obesity of I, II or III class - data are presented in Figure 2. The answers presented above translated at some point into answers to the next question.

\section{Interest in pro-health initiatives offered by employer}

The second question in the survey: "In which pro-health initiatives offered by Employer (online or at the workplace) would you participate?" consisted of 15 answers with multiple-choice option. In this question women formed $42 \%$ of the respondents $(\mathrm{N} 2=824)$ and men $58 \%(\mathrm{~N} 2=1118)$.

The results show that the greatest interest of employees was in back pain prevention $(50 \%, \mathrm{~N}=971)$. It was closely followed by stress management (49\%, $\mathrm{N}=951$ ). In the third place are the activities related to healthy eating and the financing of sports activities, including online platforms $(47 \%, \mathrm{~N}=912)$. An interest in vaccinations against COVID-19 was shown by $39 \%$ of respondents $(\mathrm{N}=757)$, which placed the initiative in the fourth place. It is worth noting that these declarations were collected before the research on the vaccine was finalized and before it was marketed. Interestingly, only $31 \%$ of respondents $(\mathrm{N}=602)$ declared their interest in vaccination against influenza.

In addition to the aforementioned initiatives employees also showed interest in the prevention of cancer, occupational burnout and vision defects (36\%, $\mathrm{N}=699)$, managing work from home (32\%, $\mathrm{N}=621$ ), prevention of musculoskeletal system diseases (31\%, $\mathrm{N}=602)$, ergonomics of the workplace $(25 \%, \mathrm{~N}=485)$ and ongoing psychological support $(21 \%, \mathrm{~N}=407)$. The total split of interest into individual initiatives offered by employer is presented in Figure 3.

\section{Following recommendations for physical activity}

Employees' interest in healthy eating and financing sport activities remains at the peak, although the results of the survey show that many employees still do not follow the recommendations. In the third question "How often do you exercise?", $23 \%$ of respondents $(\mathrm{N}=468)$ admit that they don't exercise at all and $26 \%(\mathrm{~N}=529)$ exercise but not as often as it's recommended. In this question women formed $41 \%$ of the respondents $(\mathrm{N} 3=843)$ and men 59\% (N3 = 1192). Recommendations about aerobic training (at least 75 min a week - high intensity) is followed by $35 \%$ of respondents $(\mathrm{N}=712)$. Muscles

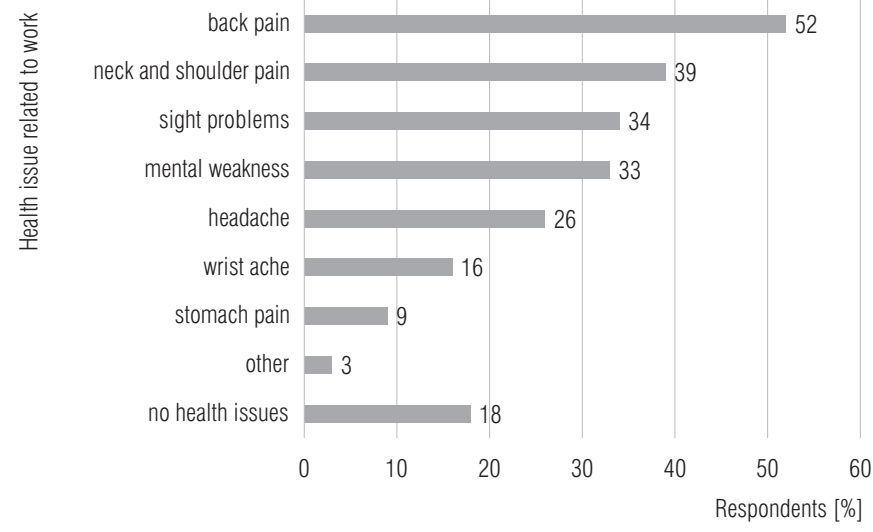

Figure 1. The answers given by 1957 respondents (office workers form different industries and blue-collar workers from the manufacturing industry) to the question "Do you suffer from any health issues related to your work specifics?" (study in Poland, September-October 2020)

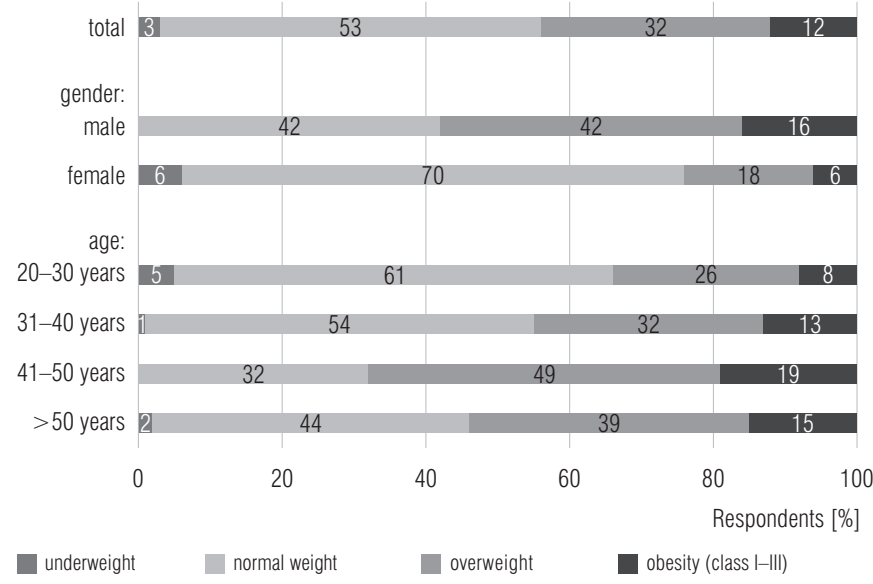

Figure 2. Split of body-mass index (BMI) among 2188 respondents by age and gender (study in Poland, September-October 2020)

strengthening exercises (at least twice a week) are performed by $31 \%$ of respondents $(\mathrm{N}=630)$. The answers to this question are presented in the Figure 4.

\section{Employees' and employers' interest in vaccination against COVID-19}

When it comes to employees' interest in vaccinations, it is behind the above-mentioned subjects. The interest declared $39 \%$ of respondents $(\mathrm{N}=757)$, which placed the initiative in the fourth place. The national trend is also far from desired level.

\section{DISCUSSION}

The conducted analysis shows information on employees' health issues related to work specifics, such as sedentary work, but also work in production, which is 


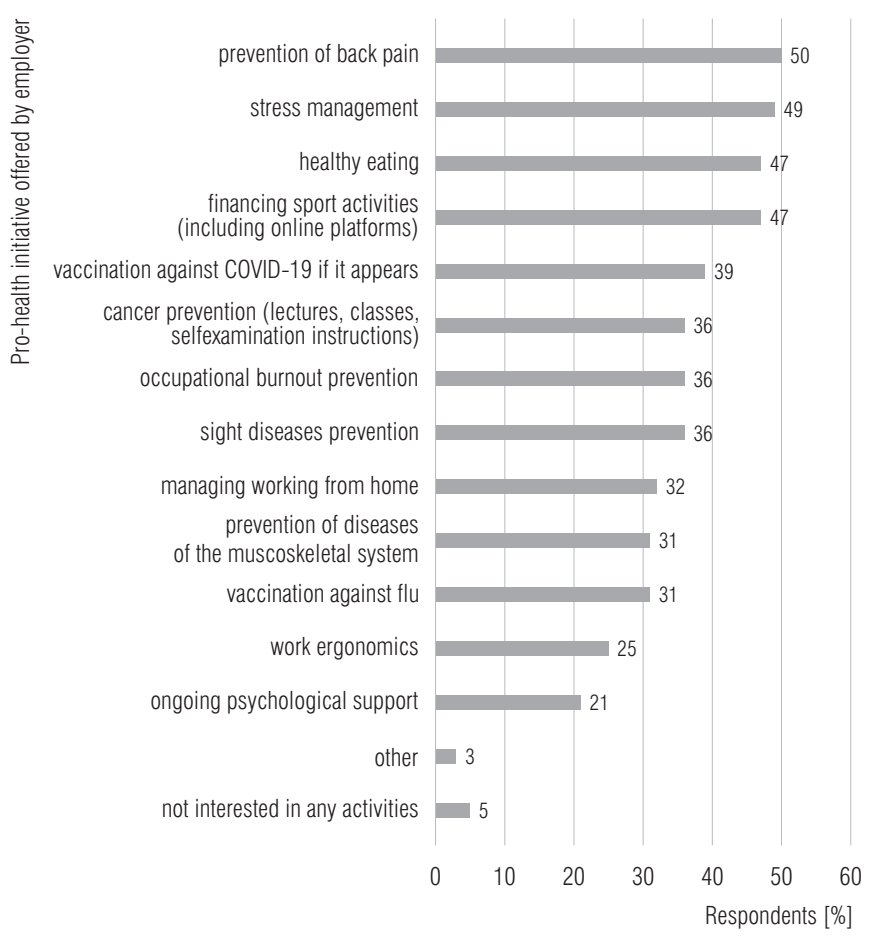

Figure 3. The answers given by 1942 respondents to the question "In which pro-health initiatives offered by employer (online or at the workplace) would you participate?" (study in Poland, September-October 2020)

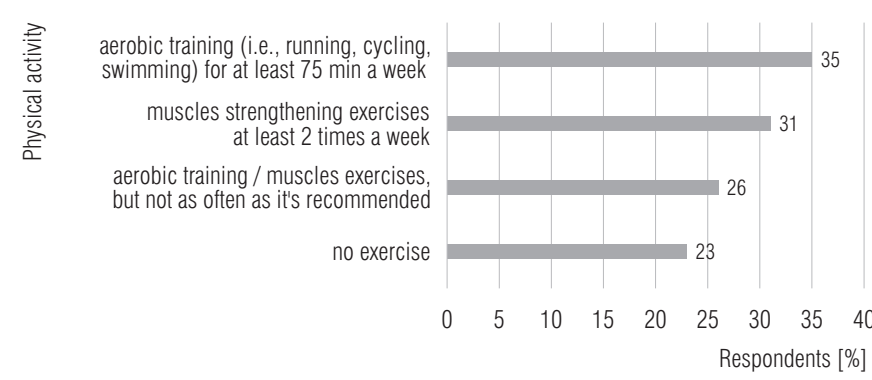

Figure 4. The answers given by 2035 respondents to the question "How often do you exercise?” (study in Poland, September-October 2020)

reflected in many other studies and publications. Two most common issues are related to musculoskeletal system. Further issues are related to sigh problems and mental weakness. According to Social Insurance Institution (ZUS), the musculoskeletal system diseases stand for $18 \%$ of annuity judgements, while mental disorders stand for $18,2 \%$ [5]. As many as $2 / 3$ of employees submit problems with bones, joints, or muscles as the most severe issues, which has also a global aspect [6]. According to the research of European Working Conditions Survey (EWCS), $43 \%$ of respondents complain on back pain and $42 \%$ on neck and shoulder pain. Yet another research shows that [7] remote work, which increased significantly during the pandemic, may bring benefits in maintaining a balance between private life and professional, which improves the overall well-being of employees.

Nevertheless, as shown by studies from before the epidemic, many employees on a daily basis experienced various types of pain related to the musculoskeletal system caused by sedentary work $[8,9]$. The answers concerning physical pain of the musculoskeletal system (back, neck, shoulders) were marked 1780 times in total. Also noteworthy is the answer regarding mental weakness of varying degrees. The impact of the COVID-19 epidemic on mental health can be observed in numerous studies, on many levels of life, causing many disorders and problems, both individual and collective.

As we know from variety of publications, stress and sedentary work have a significant impact on overweight and obesity. These in turn increases the rate of absenteeism and presenteeism, lowers the productivity and generates further costs [6]. According to the Social Insurance Institution (ZUS) data, mental and behavioral disorders cause $10,8 \%$ of sick leaves in Poland [10]. According to Main Statistical Office, 18,3\% of adults in Poland is tired permanently or most of the time [11].

The study also shows new information on employees' interest in pro-health activities organized by employer and provides data on employees' BMI. Some of the results follows national and global trends. For example, $44 \%(\mathrm{~N}=962)$ of respondents have either overweight or obesity, while $>50 \%$ of Europeans are overweight [12]. Another example shows, that $23 \%(\mathrm{~N}=468)$ of respondents don't exercise at all, while the research conducted by Main Statistical Office in 2015 showed that over half of Polish population (53\%) doesn't perform any sport activities [11].

Employees declared in the study interest in influenza vaccinations even lower, than in vaccinations against COVID-19. In the period September 2019-February $2020,>4.8$ million cases and suspected cases of flu were recorded in Poland, as well as 65 deaths due to influenza [13], while vaccination coverage was estimated at $4.12 \%$ [14]. In the same flu season in 2020-2021, during the second wave of the COVID-19 epidemic, these statistics decreased to 1.7 million cases and 0 deaths [14], and the number of vaccinated people increased up to $5.2 \%$ [15]. Flu vaccinations have been a popular initiative organized by employers at the workplace. The following season will show, if this trend is maintained and how it affects the vaccination rate.

Contrary to influenza vaccinations or even a back pain prevention or healthy eating, when organizing vaccinations against COVID-19 at the workplace, 
employers encountered new opportunities but also obligations and significant risks. Since May 4, 2021, Polish government prepared the guidelines on conducting vaccinations at the workplace [16]. According to the rules:

employer needs to find and sign an agreement with the vaccination point,

employer has to send an enrolment application providing the number of people willing to get vaccinated - this requires from employer gathering data about the potential interest of employees in vaccinations which is a subject of GDPR rules. For example, to what extent is employer authorized to gather information about employee's interest in vaccinations and when it is treated as a medical (sensitive) data?

The potential of a workplace in fighting the coronavirus seems to be used to a very small extent. Many employers are challenged in terms of data protection and processing, as well as code of conduct in the event of the adverse vaccine reactions. Other potential risks are when a significant number of employees won't be able to work after the vaccinations. This subject is sensitive and requires an organized and reliable code of conduct together with the information about the responsible entity and support for the employer.

As can be seen from the study, the interest in the future vaccine against COVID-19 did not make it to the podium. Three months after introduction of the vaccine employees could start their vaccinations, but we can also see some anti-vaccination beliefs, and this doesn't bypass the working age population [17]. Over 6 months after the first vaccination in Poland, on June 30, 2021, 34.16\% ( $\mathrm{N}=13034$ 402) of Polish population was fully vaccinated and 44\% ( $\mathrm{N}=16788252)$ received at least 1 dose. Over 3 months late later, on October 13, 51,5\% ( $\mathrm{N}=19648767)$ of Poles are fully vaccinated, which is still far from required. The total number of performed vaccinations on October 13 was 38043 351. The highest number of performed vaccinations daily was on June 3 at it was 652524 . Since then, we can observe a significant decrease of the number of performed vaccinations on a daily basis (from $>650000$ vaccinations to 30845 vaccinations on October 13) [18]. Unfortunately, the immunization rate is still far from desirable $[19,20]$.

The COVID-19 epidemic forced the implementation of many new solutions and approaches. The workplace has become one of many places with high risk of transmission of the virus which is a challenge for employers both in terms of keeping employees safe, as well as maintaining the business continuity. A several recommendations came into force, such as: delegating as many employees as possible to work remotely, limiting business trips, providing disinfectants and surface decontamination, ongoing updates about the current situation and suspension of periodical occupational medicine examinations [21].

The profitability of preventive initiatives at the workplace finds it support in many studies and reflects in lower absenteeism rate and higher productivity [6,22-24]. In Poland, most of employers' preventive actions are still limited to occupational medicine act [25]. The regulation itself dates from 1997 and needed revision for a long time. Thanks to the 2020 amendment, the occupational medicine physician will be able to conduct a full examination and comprehensive assessment of the patient and direct him in the right direction [26]. That includes the possibility of referral by an occupational medicine doctor for specialist consultation tests depending on indications, in particular: otolaryngological, neurological, ophthalmological, dermatological, allergological or psychological. In practice, this means less paperwork and a simplification of the process. Instead of compulsorily referring to specialists, the OM (occupational medicine) doctor will be able to focus, for example, on the secondary prevention of civilization diseases and on health education.

However, many employers still treat occupational medicine as cooperation with the doctor only. In turn, this cooperation should connect all parties involved, i.e., employees, employers, doctors and nurses of the occupational medicine service. It is worth using the potential of occupational health nurses, for example to monitor the place for occupational medicine, especially in production plants. The potential of preventive employee examinations in this area seems to be unused and limited especially during the pandemic.

This carries the need to consult systemic solutions with representatives of employers and occupational medicine practitioners as well as the government in order to search for the most effective solutions. Especially, that more challenges will come, such as the definition of the COVID-19 infection as an occupational disease, which is still not unified and requires further legal regulations $[21,27]$. With no doubt, activities promoting health at the workplace have a positive impact on the health potential of employees, which also has an economic aspect and leads to productivity [28] and in case of the pandemic - could effectively help in coping with coronavirus COVID-19. 
This confirms the importance of employer's engagement in promotion of vaccinations at the workplace as the key element of occupational medicine obligations and engagement in public health. However, employers' responsibility and support should be still the subject of research and consideration, in order to elaborate solutions tailored to the needs and capabilities of each group (employers, occupational medicine professionals and government). The very process of persuading and educating about the need for health care in the workplace is an element of the broadly understood health policy of the state and cannot be separated from it.

Additional comments: During the time of writing this article (August 17, 2021) the Ministry of Health in Poland was preparing a project allowing employers to check whether employee is vaccinated against COVID-19, or not. No such regulation has been introduced yet (November 10, 2021). Since October 2021 the government recommends the third "boost" dose of the vaccination for all adults, not earlier than 6 months after completing the primary immunization.

\section{CONCLUSIONS}

The research shows that $82 \%(\mathrm{~N}=1605)$ of employees have different health issues related to their work specifics. This also applies to the BMI results and following physical activity recommendations, as $32 \%$ of them are overweight $(\mathrm{N}=700), 12 \%(\mathrm{~N}=262)$ has obesity and $23 \%(\mathrm{~N}=468)$ don't exercise at all. Employees also declare interest in some health promoting activities organized by employer, but the vaccinations are not their top priority. This leads to several conclusions:

The workplace should be one of the key habitats for health promoting activities, including vaccination education. In terms of COVID-19 vaccinations it seems to be used in a very limited scope.

The above-mentioned issue should still be the subject of research and consideration, in search of solutions tailored to the needs and capabilities of each group (employers, occupational medicine professionals and government). The very process of persuading and educating about the need for health care in the workplace is an element of the broadly understood health policy of the state and cannot be separated from it.

One of the circumstances of promoting the health of employees should be preventive examinations of employees - a doctor's visit and contact with an occupational medicine nurse is an opportunity to provide health education. The potential of preventive employee examinations in this area seems to be unused and limited especially during the pandemic.

The level of immunization of employees, but also their health status in general, has an obvious impact on the state of the economy. In view of the voluntary vaccination against COVID-19, this requires educational campaigns aimed at both employees and employers.

\section{REFERENCES}

1. World Health Organization [Internet]. Geneva: The Organization; 2021 [cited 2021 Oct 13]. Available from: www.who.int.

2. Sygit M. Zdrowie Publiczne. Warszawa: Wolters Kluwer; 2017.

3. National Health Service [Internet]. London: The Organization; 2021 [cited 2021 Jun 11]. Available from: https:// www.nhs.uk.

4. Cianciara D. Zarys współczesnej promocji zdrowia. Warszawa: Wydawnictwo Lekarskie PZWL; 2010.

5. Social Insurance Institution [Internet]. Medial committee judgements issued in 2018 [cited 2021 Aug 18]. Available from: https://www.zus.pl/documents/10182/39599/Orze czenia+Komisji+Lekarskich+ZUS+wydane+w+2018+ roku.pdf/bc769e22-a10b-f757-5b23-a3ae2788aa4e.

6. Puchalski K, Korzeniowska E, editors. Promocja zdrowia w zakładzie pracy: wsparcie dla zdrowego odżywiania się i aktywności fizycznej pracowników [Internet]. Łódź: Nofer Institute of Occupational Medicine; 2017 [cited 2021 Aug 18]. Available from: http://www.imp.lodz.pl/up load/projekty/npz/monografia_promocja_zdrowia_w_za kadzie_pracy.pdf.

7. Carbal E, editor. Ergonomics and telework: A systematic review. Work 2020;66(4):777-788. https://doi.org/10. 3233/WOR-203224.

8. Celik S, Celik C, Dirimese E, Tasdemir E, Arik T, Büyükkara T. Determination of pain in musculoskeletal system reported by office workers and the pain risk factors. Int J Occup Med Environ Health. 2018;31(1):91-111. https:// doi.org/10.13075/ijomeh.1896.00901.

9. Citko A, Górski S, Marcinowicz L, Górska A. Sedentary Lifestyle and Nonspecific Low Back Pain in Medical Personnel in North-East Poland. Biomed Res Int. 2018: 1965807. https://doi.org/10.1155/2018/1965807.

10. Social Insurance Institution [Internet]. Sick absenteeism 2020 [cited 2021 Aug 18]. Available from: https://www. zus.pl/documents/10182/39590/Absencja+chorobowa_ra port_2020.pdf/6ba50f53-bbab-dc1c-f4bf-f874fdbc2561.

11. Main Statistical Office [Internet]. Quality of living in Poland 2015. The results of the social cohesion survey [cited 
2021 Aug 19]. Available from: https://stat.gov.pl/files/gfx/ portalinformacyjny/pl/defaultaktualnosci/5486/4/2/1/ja kosc_zycia_w_polsce_w_2015_roku.pdf.

12. Eurostat [Internet]. Overweight and obesity - BMI statistics; 2019 [cited 2021 Aug 23]. Available from: https:// ec.europa.eu/eurostat/statistics-explained/index.php?ti tle=Overweight_and_obesity_-_BMI_statistics.

13. National Institute of Public Health - National Institute of Hygiene [Internet]. Warsaw, The Organization; 2021 [cited 2021 Jun 11]. Epidemiological reports "Illnesses and suspicions of influenza in Poland". Available from: http:// wwwold.pzh.gov.pl/oldpage/epimeld/grypa/index.htm.

14. National Institute of Public Health - National Institute of Hygiene [Internet]. Warsaw, The Organization; 2021 [cited 2021 Jun 11]. What is the flu vaccination rate in Poland? Available from: https://szczepienia.pzh.gov.pl/faq/ja ki-jest-poziom-zaszczepienia-przeciw-grypie-w-polsce/.

15. Puls Medycyny [Internet]. Warsaw: Online magazine; 2021 [cited 2021 Jul 6]. Flu season 2020/2021: morbidity and mortality. Available from: https://pulsmedycyny. pl/sezon-grypowy-2020-2021-liczba-zachorowan-na-gry pe-i-zgonow-1105921.

16. Service of the Republic of Poland [Internet]. Warsaw: Online government portal; 2021 [cited 2021 Nov 10]. Vaccination report against COVID-19. Available from: https://www.gov. $\mathrm{pl} /$ web/szczepimysie/szczepienia-zakladow-pracy.

17. Włodarska A, Gujski M, Pinkas J, Raciborski F. The influence of socio-demographic characteristics on attitudes towards prophylactic vaccination in Poland. J Occup Med Environ Health. 2021;34(1):121-132. https://doi.org/10. 13075/ijomeh.1896.01671.

18. Service of the Republic of Poland [Internet]. Warsaw: Online government portal; 2021 [cited 2021 Oct 13]. Vaccination report against COVID-19. Available from: https:// www.gov.pl/web/szczepimysie/raport-szczepien-przeciw ko-covid-19.

19. National Institute of Public Health - National Institute of Hygiene [Internet]. Warsaw, The Organization; 2021 [cited $2021 \mathrm{Jul} \mathrm{6]}$. What is herd immunity? Available from: https://szczepienia.pzh.gov.pl/wszystko-o-szczepieniach/ co-to-jest-odpornosc-zbiorowiskowa/.

20. World Health Organization [Internet]. Geneva: The Organization; 2021 [cited 2021 Jul 6]. Coronavirus disease
(COVID-19): Herd immunity, lockdowns and COVID-19. Available from: https://www.who.int/news-room/q-a-de tail/herd-immunity-lockdowns-and-covid-19.

21. Świątkowska B, Walusiak-Skorupa J, Juszczyk G, Gierczyński R, Socha K, Lipińska-Ojrzanowska A. Health protection of employees against SARS-CoV-2 coronavirus infection causing the COVID-19 disease - the current state of knowledge and recommendations. Med Pr. 2021;72(1):6987. https://doi.org/10.13075/mp.5893.01042.

22. Pieper C, Schröer S, Eilerts A. Evidence of Workplace Interventions - A Systematic Review of Systematic Reviews. Int J Environ Res Public Health. 2019 Sep 23;16(19):3553. https://doi.org/10.3390/ijerph16193553.

23. Pereira M, editor. The impact of workplace ergonomics and neck-specific exercise versus ergonomics and health promotion interventions on office worker productivity: A cluster-randomized trial. Scand J Work Environ Health. 2019;45(1):42-52. https://doi.org/10.5271/sjweh.3760.

24. Proper K, Oostrom S. The effectiveness of workplace health promotion interventions on physical and mental health outcomes - a systematic review of reviews. Scand J Work Environ Health. 2019;45(6):546-559. https://doi. org/10.5271/sjweh.3833.

25. Marcinkiewicz A, Wojda M, Walusiak-Skorupa J, Hanke W, Rydzyński K. Analysis of tasks of occupational health services accomplished in Poland, 1997-2014. Do we exploit the full potential of prophylactic examinations of workers? Med Pr. 2017;68(1):105-119. https://doi.org/ 10.13075/mp.5893.00509.

26. [Regulation of the Minister of Health of 12 November 2020 changing the regulation on medical examinations of employees, the scope of preventive health care for employees and medical certificates issued for the purposes provided for in the Labor Code. J Laws 2020, item 2131]. Polish.

27. Agius RM, Robertson JFR, Kendrick D, Sewell HF, Stewart M, McKee M. Covid-19 in the workplace. BMJ 2020;370:m3577. https://doi.org/10.1136/bmj.m3577.

28. Mills PR, Kessler RC, Cooper J, Sullivan S. Impact of a Health Promotion Program on Employee Health Risks and Work Productivity. Am J Health Promot Sep-Oct 2007;22(1):45-53. https://doi.org/10.4278\%2F0890-117122.1 .45

This work is available in Open Access model and licensed under a Creative Commons Attribution-NonCommercial 3.0 Poland License - http://creativecommons.org/licenses/by-nc/3.0/pl/deed.en. 